\title{
Closing Gender Gaps in Climate-Smart Agriculture through Strengthening Women Rice Seed Farmer's Capacities and Access to Quality Stress-tolerant Seed in Benin
}

\author{
Esperance Zossou $^{1,2}$, Afiavi R. Agboh-Noameshie ${ }^{2}$ \& Alidou Assouma-Imorou ${ }^{1}$ \\ 1 Laboratoire de Sociologie et Vulgarisation Rurales, Faculté des Sciences Agronomiques, Université \\ d'Abomey-Calavi, Bénin \\ ${ }^{2}$ Previous Affiliation: Africa Rice Center, Cotonou, Benin \\ Correspondence: Espérance Zossou, Laboratoire de Sociologie et Vulgarisation Rurales, Faculté des Sciences \\ Agronomiques, Université d'Abomey-Calavi, Bénin. E-mail: esperancezossou@gmail.com
}

Received: March 23, 2020 Accepted: May 11, $2021 \quad$ Online Published: May 29, 2021

doi:10.5539/sar.v10n3p41 URL: https://doi.org/10.5539/sar.v10n3p41

\begin{abstract}
Climate change and stress conditions (drought; submergence, salinity, iron toxicity, and cold) disproportionately affect the poorest and most disadvantaged rice farmers, forcing them deeper into poverty. Recent advances in genetics and breeding enable the development of rice varieties tolerant of these abiotic stresses and their cultivation can substantially contribute to poverty alleviation in unfavourable environments and for poor rice consumers globally. Through the program Stress-Tolerant Rice for Africa and South Asia (STRASA), fourteen new stress-tolerant varieties were released, produced and distributed in Sub-Saharan Africa to reach millions of poor farmers. However, ignoring women's contributions to agriculture and particular in seed production and failing to design strategies to reach them with new varieties miss significant opportunities to reduce poverty. This study investigates on gender issues in rice seed production in Benin through a gender analysis of the division of labour, access and control of resources, livelihood, and constraints and opportunities faced. Both qualitative and quantitative data were collected with 29 women and 29 men seeds producers using both the Harvard Analytical and the Sustainable Livelihoods Frameworks. Data showed that women are central in rice seed production; but are marginalized in their access and control of resources. Given to women resources property rights as well as improving their control on resources will help them to be more performant as seed producers. These areas for action are important in designing and implementing activities in gender-responsive ways for sustainable Stress-Tolerant Rice seed multiplication, dissemination and out scaling in Africa.
\end{abstract}

Keywords: gender, climate change, rice seed, abiotic stresses, Benin

\section{Introduction}

Climate smart agriculture (CSA) is an integrative approach that combines adaptation and mitigation of climate change, with links to environmental, social and economic pillars of sustainability. It covers farm level practices, landscape level approaches, institutional, and policy level frameworks (FAO, 2010, World Bank \& CIAT, 2015; FAO, 2013, Lipper et al., 2014; Zoundji, Witteveen, Vodouhê \& Lie, 2017; Zoundji, Vodouhê, Okry, Bentley \& Tossou, 2018). CSA leads to ensure proper management of resources such as soils, water, genetic resources, pest and disease control that will increase productivity, protect the environment, adapt and mitigate climate change (FAO \& World Bank, 2011). Among genetic resources, seeds are important and delicate product to handle.

Seed is a fundamental input to crop production, embodying specific genetic information as well as important physical qualities. As such, its commerce offers particular challenges and opportunities (Tripp \& Rohrbach, 2011). Seed is complex, and practical solutions aimed at enabling farmers to access and effectively utilize new and existing varieties in a sustainable and cost-effective manner are context-specific.

Specializing in seed production is difficult because producing and distributing high quality seed often require adequate investment in labour, machinery, pesticides, processing and storage facilities, packaging and marketing (Guei, Barra \& Silue, 2011). Consequently, few farmers specialize in seed production (Okry, Van Mele, Nuijten, Struik \& Mongbo, 2011). 
In Sub Sahara Africa, farmers are unable to access quality seed. The dependency of the formal seed system on the extension system limits the number of farmers, mainly women, it can reach (Guei, Barra \& Silue, 2011). Moreover, women are limited by social norms in communicating with men outside their families and do not benefit as much as men from extension programmes for farmers (Katungi, Edmeades \& Smale, 2008, Zossou, Arouna, Diagne \& Agboh-Noameshie, 2017; Zossou, Arouna, Diagne \& Agboh-Noameshie, 2020). Consequently, the seed system is dominated by the informal sector (Almekinders and Louwaars, 2002); with a prevalence of farmer's saved seed (Seboka \& Deressa, 2000) in developing countries.

In response to the failure of the formal seed system to provide good quality seed for small scale farmers (Wiggens \& Cromwell, 1995), Seboka \& Deressa (2000) suggest taking into account positive attributes of both formal and informal seed systems with a redefinition of the role of extension services. Van Mele et al. (2011) showed that many African seed enterprises can bring together the formal and informal seed sectors in rather innovative ways, thereby assuring a flow of improved seeds to small farmers through the community-based seed system (CBSS).

In the rice sector in Benin, the multiplication of foundation seeds is carried out by the national agriculture research institute. Certified seeds are produced by the community-based seed system that is a middle ground between the farmer system and the public sector that attempts to bridge the formal and the informal rice seed system. It is a participatory attempt of combining scientific principles of seed development and traditional practices of seed production, conservation and distribution. However, the seed sector is still dominated by the public sector because the participation of farmers seed producers in marketing is low or even marginal. The quantities to be produced and the prices are under the control of public sector (Van Mele, Bentley \& Guei., 2011).

Recent advances in genetics and breeding facilitate the development of rice varieties tolerant of these abiotic stresses as well as their cultivation can substantially contribute to poverty alleviation in unfavourable environments and for poor rice consumers globally. Stress-Tolerant Rice for Africa and South Asia (STRASA) program aims to develop and deliver rice varieties tolerant of abiotic stresses to millions of less fortunate farmers who depend on rice farming in unfavourable rainfed areas of South Asia (SA) and sub-Saharan Africa (SSA). Thirty new stress-tolerant varieties were released, 16 in SA and 14 in SSA using participatory varieties selection (PVS), and more than 140,000 tons of seed were produced and distributed, reaching 10 million farmers. A collaboration between International Rice Research Institute (IRRI) and AfricaRice, with support from Bill and Melinda Gates Foundation, Phase 3 of the STRASA program began in 2014 with the aim of producing 275,000 tons of high-quality seed of stress-tolerant varieties and facilitating adoption of the new varieties and technologies by 25 million farmers in South Asia (SA) and Sub-Saharan Africa (SSA). Considering the importance of women in seed production, greater efforts need to be made to ensure that women are among the farmers benefitting from these innovations.

To ensure that women are among the farmers benefiting from this innovation, a workshop was initiated in Benin Republic from June 15 to 21,2015 to strengthen women rice seed producers' capacities in agribusiness, leadership and the production and multiplication of stress-tolerant rice seeds. This article sights to investigate Climate-Smart Agriculture issues in relation with gender analysis in rice seed production, with potential ways to close the gaps.

\section{Method}

An exploratory phase using focus group discussion and semi-structured interviews was held from 18 to 21 May 2015 in Dassa and Glazoue municipalities (central region of Benin) to collect data on the constraints and opportunities faced by female and male rice seed producers and select women who will benefit from the training on seed production. A total of 10 focus group discussion were held, 5 with female rice seed farmers and 5 with male rice seed farmers. Five key informants from agricultural research and extension public services closed to the rice seed farmers were interviewed.

The workshop was held from June 15 to 21, 2015 in Dassa with 29 female rice seed farmers and four facilitators from public agricultural extension services. The workshop aimed to strengthen the capacities of participants and focused on 3 modules namely: (i) Baseline data collection, (ii) Production of quality rice seeds, and (iii) Entrepreneurship and Leadership. The baseline data were collected with the 29 female farmers who attended the workshop. The same baseline data were collected with 29 male rice seed farmers, randomly selected in the same living areas of the surveyed women who attended the workshop. Qualitative and quantitative data were collected individually and in focus group discussion using 5 main steps: (i) focus group discussion on the components of the five livelihood assets (social, financial, human, physical and natural capitals); (ii) individual survey using a 
structured survey questionnaire to collect socio-demographic data; (iii) a second focus group discussion on the activity profile, access and control of resources; (iv) a second individual survey to get individual scores of capitals assets through scores from 0 to 5 and the causes that explain the state of livelihood assets; and (v) a third focus group discussion to identify the constraints and opportunities in rice seed production. The focus groups data were collected in homogenous group according to the gender.

A year later, 10 of the 29 women who attended the workshop were randomly selected and surveyed using a semi-structured interview guide in order to capture the outcomes of the workshop.

Data were analysed using descriptive statistics (mean, standard deviation, frequency, percentage). The Harvard Analytical and the Sustainable Livelihoods Frameworks were used for a gender analysis of the division of labour, the access and control of resources, the livelihood, and the constraints and opportunities.

\section{Results and Discussions}

\subsection{Socio-demographic Information}

Table 1. Definition of variables and socio-economic profile of surveyed rice seed producers

\begin{tabular}{lllll}
\hline Variables & Description & Parameters & Value & \\
\cline { 4 - 5 } & & & Men (n=29) & Women (n=29) \\
\hline Age & Age in years & Mean (std. dev) & $46(4)$ & $41(9)$ \\
Gender & Man or woman & Percentage (\%) & 50 & 50 \\
Ethnic group & Northern ethnics & Percentage (\%) & 3 & 35 \\
& Fon and related & Percentage (\%) & 23 & 10 \\
Marital status & Yorouba and related & Percentage (\%) & 74 & 55 \\
& Married & Percentage (\%) & 100 & 76 \\
Household size & Widower & Percentage (\%) & 0 & 24 \\
& Number of individuals & Mean (std. dev) & $8(2)$ & $7(2)$ \\
Education & in household & & & \\
& None & Percentage (\%) & 9 & 66 \\
& Local language & Percentage (\%) & 0 & 3 \\
Main activity & Primary & Percentage (\%) & 51 & 17 \\
\multirow{2}{*}{ Income } & Secondary & Percentage (\%) & 40 & 14 \\
\multirow{2}{*}{ Group membership } & Agriculture & Percentage (\%) & 100 & 97 \\
& Processing & Percentage (\%) & 0 & 3 \\
\hline
\end{tabular}

${ }^{a}$ At the time of the experiments, i.e. May 2015, the currency rate was $\$ 1=589.81$ FCFA.

The table 1 shows the socio-demographic information of the surveyed rice seed farmers. With an average age of 46 years, men are slightly older than women for whom the average age is 41 years. All men are married with an average number of 8 members per household. In comparison, only $76 \%$ of women are still living with their husbands, the remaining (24\%) being widows. About the ethnic group, the majority of the surveyed farmers are Yoruba and related. The access to education is very low among women, with $66 \%$ without any school education compared to only $9 \%$ among men. Men have about 5 times more monthly income than women. Both men and women have farming as their main activity.

\subsection{Gender Gap in the Division of Labour in Rice Seed Production}

A gender analysis of the division of family and wage labour using the Harvard Analytical Framework shows that men are more involved in the pre-harvest activities in certified rice seed production; while women in the post-harvest activities. 


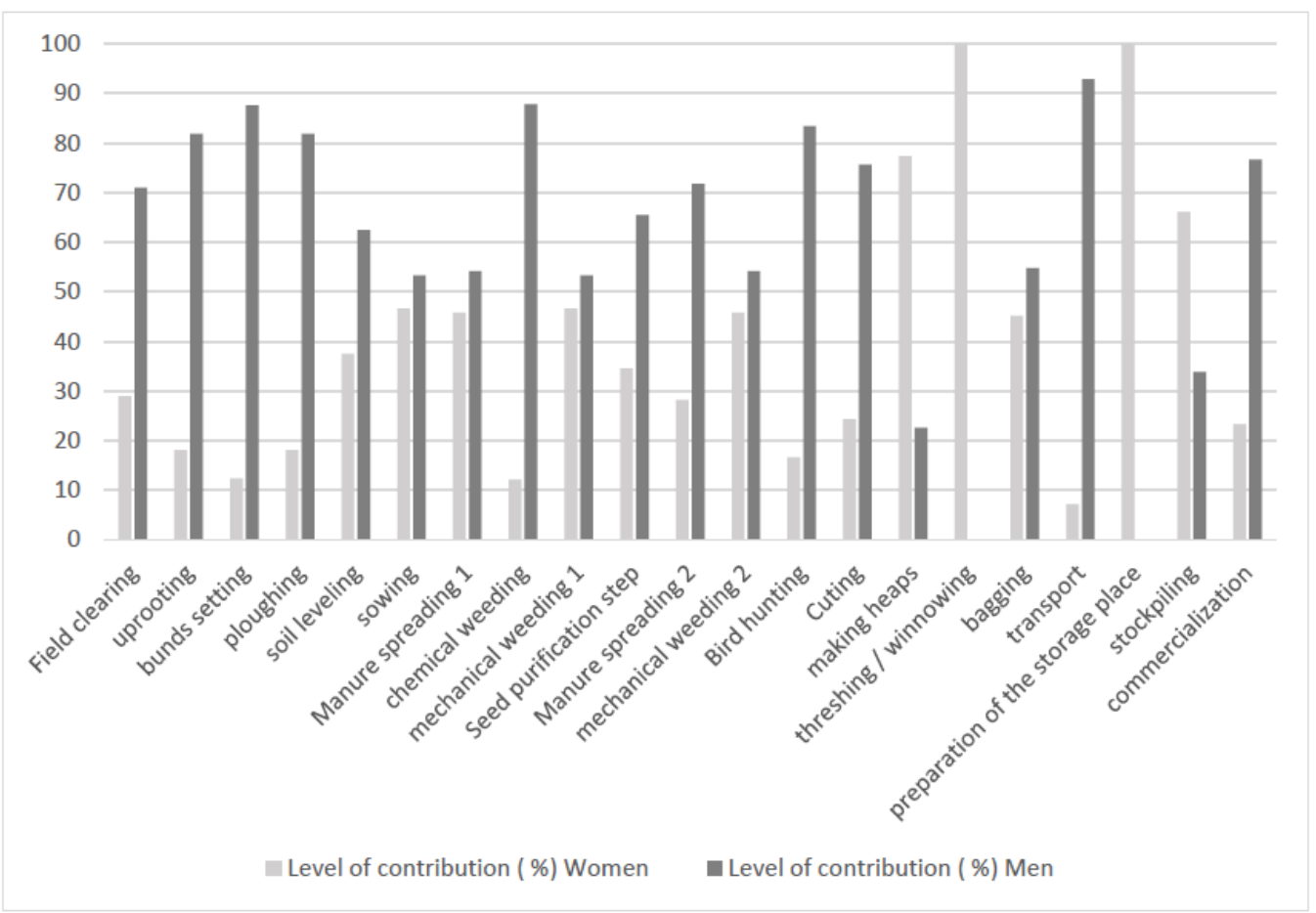

Figure 1. Activity profile for both family and wage labor used in rice seed production

Women contributions in the pre-harvest and post-harvest activities are on average 30\% and 55\%, respectively. This contribution in rice seed production is significant and show that women and men play seemingly equal role in agriculture and particularly in rice seed production. The role of women in crop seed production in Africa is more important than that of men in some previous studies findings. According to Sogani (2011), women's contribution in various seed production, not just with respect to several tasks performed but also in terms of time spent, is much higher compared to men. A study in Guinea shows that about $80 \%$ of the members of the cereal and potato seed producers' union are women, eager to earn an income and feed their families (Okry et al., 2011). Just as seed is central in agriculture, so are women central as seed keepers, knowledge holders and small farmers in their own right (Bhutani, 2013).

Seeds are critical in the food chain and women's roles as seed savers and breeders have been largely responsible for keeping the diversity alive (Sogani, 2011). However, despite their contributions to seed production, women are often overlooked as farmers, innovators, and entrepreneurs (FAO 2011). Farmers interested in becoming seed producers must have ties with research and plant breeders to get the 'foundation seed' needed to grow certified seed. This is a challenge for women farmers due to the gender bias noted in their collaboration with research and development agents (Katungi et al., 2008; World Bank, 2008). Addressing gender issues in seed production and dissemination efforts will contribute to yields increase and hunger reduction.

\subsection{Climate Change as Main Constraint in Rice Seed Production}

The top five constraints affecting rice seed production according to women are climate change issues, access to agricultural inputs, decline in soil fertility, access to information and knowledge, and access to the formal market. According to men, the top five constraints climate change issues, decline in soil fertility, lack of equipment and agricultural machinery, access to the formal market, and access to agricultural inputs. Among the constraints affecting rice seed producers in Benin, climate change was ranked as the first one by both men (77.14\%) and women (88.62\%). This confirms previous findings showing that climate change issues and stress conditions (drought; submergence, salinity, iron toxicity, and cold) disproportionately affect small farmers and most disadvantaged women farmers, forcing them deeper into poverty (Dankelman, 2010; Van Aelst \& Holvoet, 2016; Resurrección, Bee, Dankelman, Park, Halder \& McMullen, 2019). 


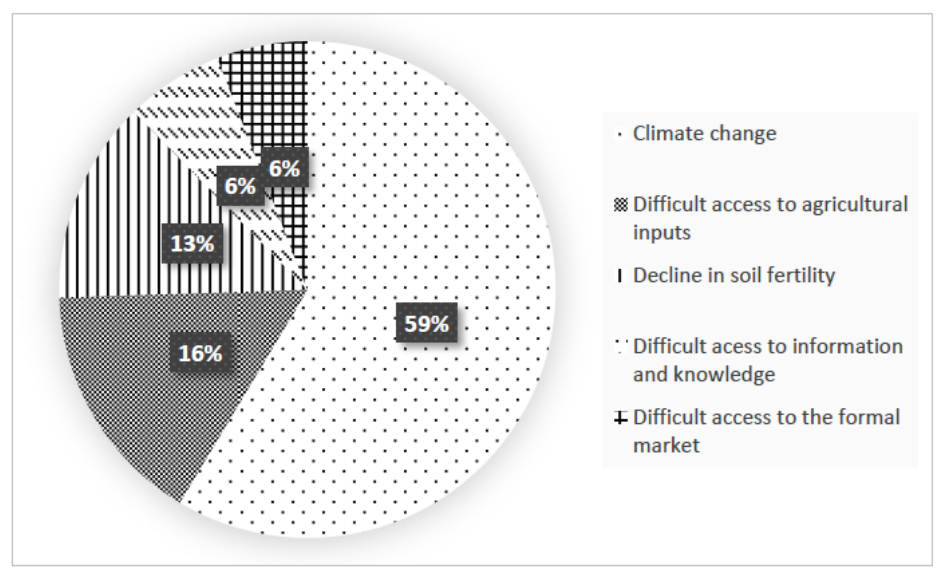

Figure 2. The top five constraints in seed production according to women rice seed producers

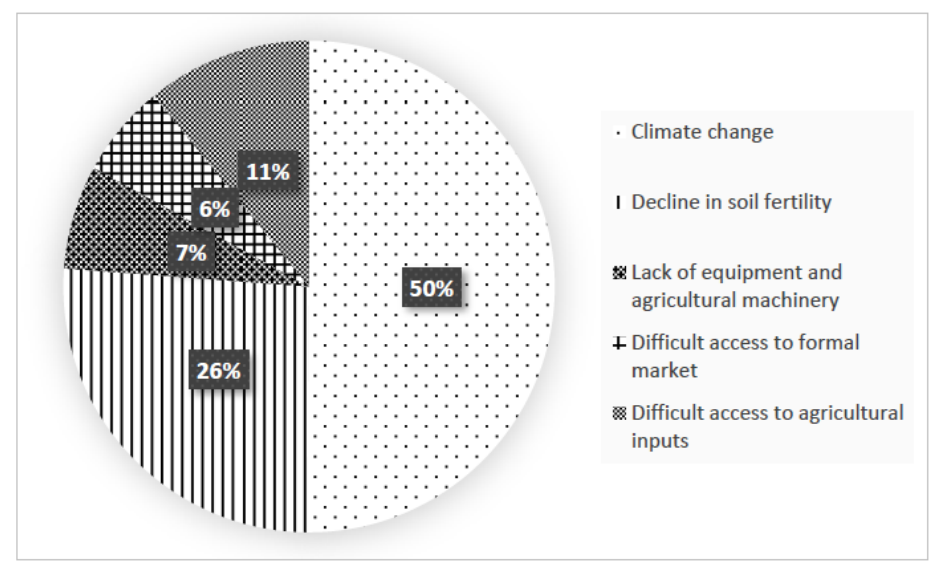

Figure 3. The top five constraints in seed production according to men rice seed producers

The indicators used by women and men to characterize climate change issues include: (i) late or early arrival of rainfall, (ii) rainfall scarcity or abundance, (iii) flooding / submergence of fields, and (iv) drought. These constraints negatively impact their farming activities. Within the difficulties in planning their field activities, they often record heavy losses, leading to reducing areas of crops production.

\section{Gender gap in the access, property right and control over resources in rice seed production}

Access, property and control level of resources are important in seed production.

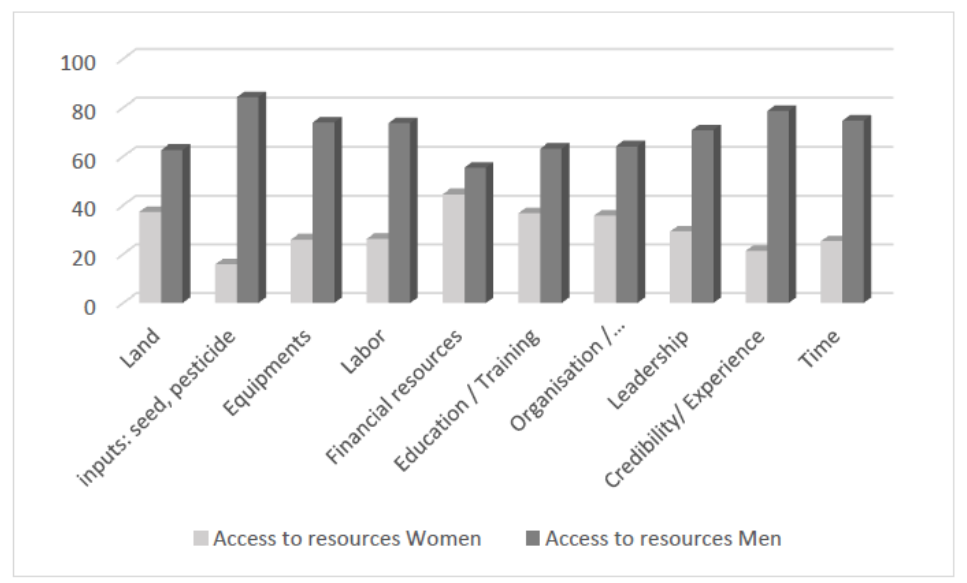

Figure 4. Gender gap in the access to resources using the Harvard Analytical Framework 


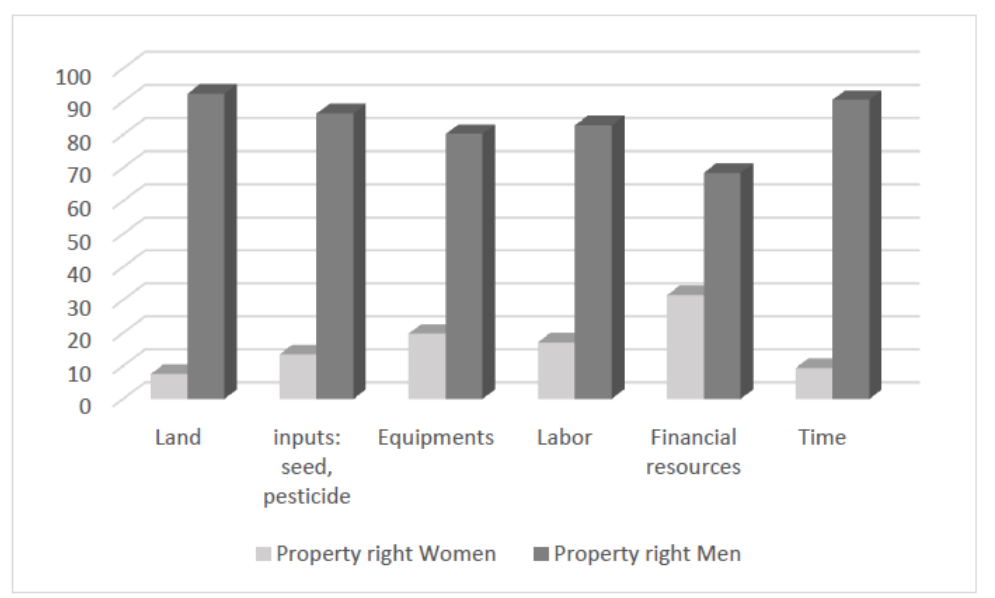

Figure 5. Gender gap in the property right over resources using the Harvard Analytical Framework

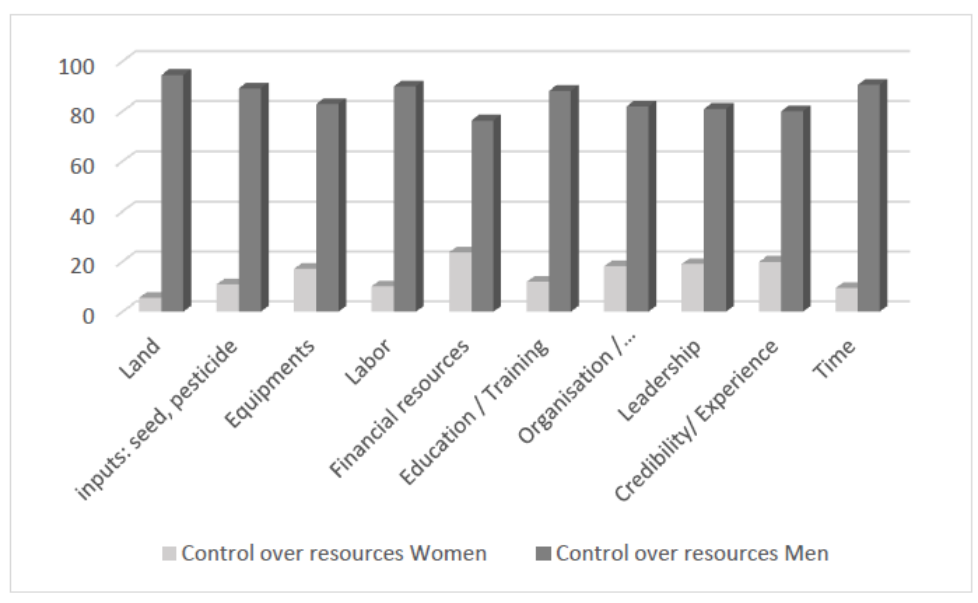

Figure 6. Gender gap in the control over resources using the Harvard Analytical Framework

Men have on average 2.35 times more access to rice seed production resources than women. The top 5 main resources to which men have more access than women are inputs (seeds, fertilizers and pesticides); credibility and experiences; time; agricultural equipment; and both wage and family labour. Women have on average 7.2 times less property right over rice seed production resources. The top five resources with low female property rights are land, time, inputs (seeds, fertilizers and pesticide), labour, and agricultural equipment. With respect to the control over resources, men have on average 10.2 times more compared to women.

These findings confirm that women continue to have less access, property right and control over agricultural resources compared to men despite the seemingly equal roles they play in agriculture in many developing countries (Croppenstedt, Goldstein, \& Rosas, 2013; Anaglo, Boateng, \& Boateng, 2014). Despite their important role and valuable contribution in seed production, female rice producers are marginalized in their access, property and control over resources. These shortfalls are among the main reasons for agricultural segregation keeping female farmers in poverty in Africa. The property right and control over agricultural resources are particularly important for female farmers' commitment to sustainable agriculture in Africa (Anaglo et al., 2014).

\subsection{Gender Gap in Livelihood Capital Assets}

The components of livelihood assets were approximatively the same for women and men. Men have better asset on financial, human and natural capitals; while women have better asset on social capital. The physical capital asset is seemingly the same for both male and female rice farmers. 


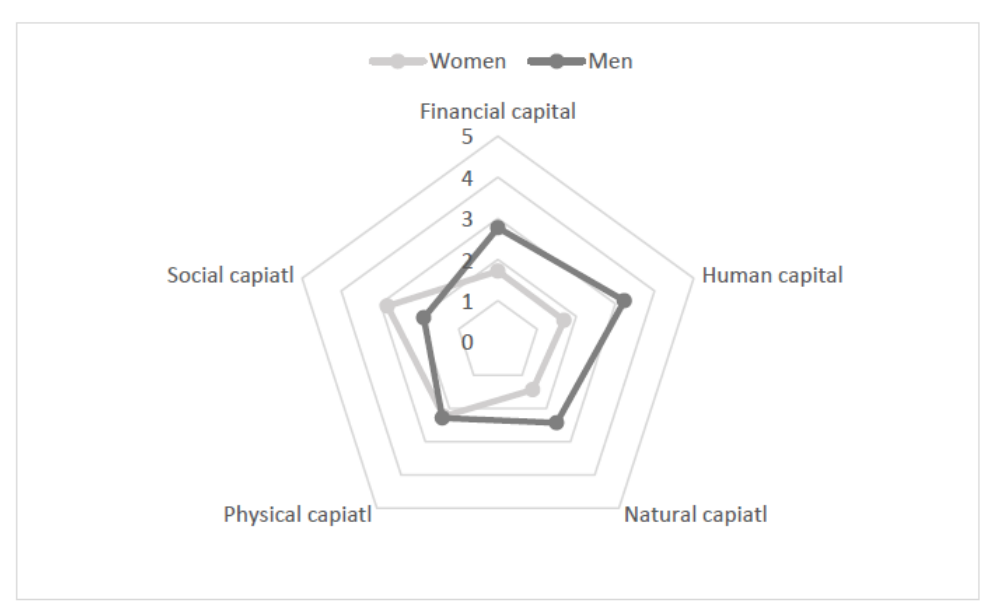

Figure 7. Gender gap in livelihood assets using the sustainable livelihood approach

Table 2. Gender perception on the main components of the five livelihood capitals in rice seed production

\begin{tabular}{|c|c|c|}
\hline \multirow[t]{2}{*}{ Capitals } & \multicolumn{2}{|l|}{ Entities } \\
\hline & Women perception & Men perception \\
\hline Financial & $\begin{array}{l}\text { Incomes, Large area of field, Children schooling, } \\
\text { Foods, goods and needs, Financial resources for } \\
\text { ceremonies and Clothing, Rate of saving, Easy } \\
\text { access to microfinance, Easy access to market }\end{array}$ & $\begin{array}{l}\text { Good quality house, Large area of field, } \\
\text { Level of polygamy, Cattle farming, Annual } \\
\text { incomes, Availability of food, Children } \\
\text { having finished university school }\end{array}$ \\
\hline Human & $\begin{array}{l}\text { Knowledge of rice seed production, Training on rice } \\
\text { seed production techniques, Ability / skill to use / } \\
\text { adopt new knowledge and technologies, Good health } \\
\text { Happiness }\end{array}$ & $\begin{array}{l}\text { Good health, physical strength, Knowledge, } \\
\text { Training, Skill / Ability }\end{array}$ \\
\hline Natural & $\begin{array}{l}\text { Climate and weather, Hydrological resources, } \\
\text { Lowland / upland/ Forest, Animals }\end{array}$ & $\begin{array}{l}\text { Climate and weather, Hydrological } \\
\text { resources, Lowland / upland/ Forest, } \\
\text { Animals }\end{array}$ \\
\hline Physical & $\begin{array}{l}\text { Irrigation shemes, Agricultural equipments, Hospital } \\
\text { and public services, Electricity Markets, Facilities } \\
\text { for drinking water }\end{array}$ & $\begin{array}{l}\text { Irrigation shemes, Agricultural equipments, } \\
\text { Hospital and public services, Electricity }\end{array}$ \\
\hline Social & $\begin{array}{l}\text { Solidarity, Group cohesion, Information and } \\
\text { experience exchange, group sales of rice seeds, } \\
\text { Team work spirit, Commitment. }\end{array}$ & $\begin{array}{l}\text { Solidarity, Information and } \\
\text { exchange, Team work spirit, }\end{array}$ \\
\hline
\end{tabular}

The lower asset of female farmers on financial, human and natural capitals is probably related to their low access and limited property right and control over agricultural resources, thus female farmers cannot take advantage from resources and value them properly (Croppenstedt et al., 2013). Moreover, in rural areas in Africa, women are disadvantaged by men from extension programs to improve their human capital because of sociocultural constraints (Kondylis, Mueller, Sheriff, \& Zhu, 2016; Zossou et al., 2017; 2020).

The higher asset of female farmers on social capital is consistent with Whitehouse (2011) and Zossou et al. (2017) who showed that people in sub-Saharan Africa, particularly women, attach importance to social capital.

The sustainable livelihoods framework is a participatory method that involves farmers as participants in the research and focuses on a process of sequential reflections and actions carried out with and by target people rather than on them (Cornwall \& Jewkes, 1995). The use of this framework guides farmers during the survey in conceptualizing components and stocks of their livelihood capitals. According to Carney (1999), livelihood approaches work with people, supporting them to build up on their own strengths and realize their potential, while at the same time acknowledging the effects of policies and institutions, and external shocks and trends.

\subsection{Participative and Inclusive Workshop and Beyond}

After the collection of socio-demographic data and interviews, the training focused on strengthening the capacities of women on two main modules namely: (i) the production / multiplication of quality stress-tolerant 
rice seeds; and (ii) entrepreneurship and leadership.

The capacity building of women on the production / multiplication of quality stress-tolerant rice seeds was done on four main sub-modules which were presented by experts from the National Agricultural Research Institute called 'Institut National de Recherche Agricole au Bénin (INRAB)'. The sub-modules presented are: (i) Knowledge of the rice plant; (ii) The quality of rice seeds and certification procedures; (iii) Cultural practices in the production of rice seeds; and (iv) Stress tolerant rice seed dissemination approaches.

The sub-module knowledge of the rice plant included information relating to the growth and development stages of the rice plant, the types of rice cultivation, the national seed system, the definition of seed, and the quality of a rice seed.

The sub-module on the quality of rice seeds and certification procedures was presented to make participants aware of the good quality that a seed must have as well as the different roles that each actor must play in the seed system. A particular emphasis was also placed on the preliminary arrangements to be made during the growing season, precisely the technical and administrative arrangements, the choice of the foundation seed and the choice of the production site.

The sub-module on cultivation practices provides information on the preliminary arrangements to be made before the start of the season and the technical itinerary to be followed. From the various exchanges, it emerges that a good success of the campaign is based on the planning of activities, the assessment of material and financial needs and a good and regular monitoring of the field. The technical itinerary to be followed concerns: the preparation of the production site, the sowing, the fertilization, the monitoring of the crops, the rouging, and the operations of harvest and post -harvest.

The communication on stress-tolerant rice seed dissemination approaches focused on variety selection and dissemination approaches. A participatory varietal selection approach was used and involved farmers, extension agents and researchers. The use of this approach led to the development of two varieties for lowland rice cultivation in Benin: NERICAL-19 and NERICAL-56. Regarding upland rice cultivation, three varieties have been developed: R16 (CNAX3031-78-2-1-1-1), R58 (WAB-56-77), and R77 (ART3-7-L6P5- BB-3). All of these varieties are resistant to lodging, drought, and flooding. The out-scaling approaches that are being used are: farmers field schools, contact groups, Training and Visit, Farmers field days, and agricultural advisory.

The capacity building workshop used a combination of four main approaches namely: masterful presentations, interactive presentations, individual and group works. This workshop ended with a field visit to the INRAB rice seed stores in Glazoué municipality. It allowed participants to see closely the quality of foundation and certified seeds as well as the conditions met for their proper storage.

The capacity building of women rice seed producers on entrepreneurship and leadership aimed to help women make certified rice seed production a successful business while adopting appropriate leadership attitudes. Four sub-modules were the components of this second part of the training: (i) Understanding of Business-Entrepreneur-Entrepreneurship concepts; (ii) Advice in the practice of entrepreneurship; (iii) Understanding of Leader-Leadership concepts; and (iv) Advice in the practice of leadership.

The perception of 4 randomly selected participants on the training is summarized in the following table. 
Table 3. Summary of participants' perception on the workshop

\begin{tabular}{|c|c|}
\hline Participants & Declaration \\
\hline $\begin{array}{l}\text { Participant } \\
\text { A.A. }\end{array}$ & $\begin{array}{l}\text { "We are very happy to participate in this training which will positively impact our life because it } \\
\text { is rich in knowledge and information. We are committed to putting into practice the learnt points } \\
\text { both on the production of quality seeds to face climate change issues and on leadership and } \\
\text { entrepreneurship." }\end{array}$ \\
\hline $\begin{array}{l}\text { Participant } \\
\text { M.E. }\end{array}$ & $\begin{array}{l}\text { "This training not only strengthened our human capital through the knowledge acquired; but also, } \\
\text { our social capital through the relationships that enrich our address book. In rural areas, we are } \\
\text { marginalized in the learning process because of socio-cultural constraints that prevent us from } \\
\text { communicating freely with our male peers and extension workers. We are facing a lot of changes } \\
\text { on climate change and we promise to work hard to address them with these acquired knowledges } \\
\text { and we will be honoured at the final assessment of this learning outcomes." }\end{array}$ \\
\hline $\begin{array}{l}\text { Participant } \\
\text { B.A. }\end{array}$ & $\begin{array}{l}\text { "We are too overburdened as women living in the rural world with our domestic activities. We } \\
\text { therefore fail to reveal our side of entrepreneur and leader. This workshop gave us tips to get } \\
\text { there and especially what it takes to face the impacts of climate change that affect us a lot. We } \\
\text { pledge that the seeds will be produced and redistributed to other women rice farmers." }\end{array}$ \\
\hline $\begin{array}{l}\text { Participant } \\
\text { A.D. }\end{array}$ & $\begin{array}{l}\text { "Day by day, we are weakened in the exercise of our activity due to the complex climate change } \\
\text { challenges. We feel more affected as women because we are limited in access, control and } \\
\text { property rights over resources. This workshop is welcome because it strengthens our knowledge } \\
\text { and capacities to innovate and appropriately these issues. We will be very united among women } \\
\text { for the access of the majority to the seeds that will be produced." }\end{array}$ \\
\hline
\end{tabular}

The facilitators present at this training were encouraged to give feedback on the training to their colleagues working in the villages or production areas of women rice seed producers. Once back in their workplaces, they were asked to provide all the necessary technical support to the women trained to put the learning outcomes into practice in order to have good results. They were also responsible for supervising the women in the seed production process after having previously established a provisional operating account and planning activities for the growing season.

Out of 10 women monitored after the training, two were unable to carry out their activities beyond the establishment of the nurseries because of the flood which damaged their fields.

Eight (08) out of ten women were able to successfully carry out transplanting, fattening, maintenance, purification and irrigation activities. These activities were carried out under the supervision of facilitators who received technical support from CARDER (Benin agricultural and extension service). After the validation of the selected fields by the technical agents from CARDER, the process of producing certified seeds was then executed using formal multiplication contracts.

In accordance with the process of producing new varieties of certified seeds, a control of the fields was successfully carried out by the General Directorate of Quality Control of Agricultural Products. All the eight women followed were able to sell their products to rice producers living in the same rice-growing communities. They have reached on average 20 women and 35 men rice producers.

Further initiatives are needed to analyse the sustainability in the adoption of these quality Stress-Tolerant seeds by women and the impact on their sustainable livelihoods.

\section{Conclusion and Implications}

Many socio-cultural barriers constraint women in their access to update agricultural information, knowledge and technologies. Although some women manage to overcome these barriers, they face other constraints related to economic conditions, access to resources, property rights and control over resources. To improve attention to gender in seed multiplication and dissemination, there is a need to design and implement activities in gender-responsive ways outlining key areas for action and providing an initial set of recommendations.

The key areas identified are as followed:

- Develop a context specific approach with a participatory and inclusively involvement of traditional chieftaincies, local culture guardians, local opinion leaders, governments, and international and domestic agriculture companies to define sustainable strategies to address socio-cultural barriers affecting rural women in their access and control of agricultural resources. 
- Use interactive rural learning and information approaches (based on traditional and new technologies of information and communication) to make agricultural technologies well known and improve the ability of women to adopt and or innovate with local or limited resources.

- Strengthen the capacities of rural women in agribusiness and leadership to take advantage of the market opportunities in agricultural value chains.

- Multi-dimensional empowerment of rural women (economic, political, social, spiritual, legal, religious and cultural) with brokers collaboration between traditional chieftaincies, governments, international and domestic agriculture companies, financial institutions, seed producers and smallholder farmers.

These areas for action are important in designing and implementing activities in gender-responsive ways for sustainable agricultural value chains seed multiplication and dissemination within the climate change issues in Africa. Removing gender inequalities in agricultural research for development and extension will accelerate the realization of development goals, such as reducing poverty and increasing food security.

\section{Acknowledgements}

The Authors are grateful to Africa Rice Centre for funding this research through the STRASA project

\section{Reference}

Almekinders, C. J. M., \& Louwaars, N. P. (2002). The importance of the farmers' seed systems in a functional national seed sector. Journal of New Seeds, 4(1/2), 15-33. https://doi.org/10.1300/J153v04n01_02

Anaglo, J. N., Boateng, S. D., \& Boateng, C. A. (2014). Gender and Access to Agricultural Resources by Smallholder Farmers in the Upper West Region of Ghana. Journal of Education and Practice, 5(5), 1-19.

Bhutani, S. (2013). Re-Searching Agriculture in South Asia: The law and policy context for agricultural research and development and its impact on smallholder farmers. IIED, London.

Carney, D. (January, 1999). Approaches to sustainable livelihoods for the rural poor. ODI Poverty Briefing 2, Overseas Development Institute, London, UK. Retrieved from http://www.odi.org.uk/resources/download/2276.pdf

Cornwall, A., \& Jewkes, R. (1995). What is participatory research. Social Science \& Medicine, 41, 1667-1676. https://doi.org/10.1016/0277-9536(95)00127-S

Croppenstedt, A., Goldstein, M., \& Rosas, N. (2013). Gender and Agriculture: Inefficiencies, Segregation, and Low Productivity Traps. The World Bank Research Observer, 28(1), 79-109. https://doi.org/10.1093/wbro/lks024

Dankelman, I. (2010). Gender and climate change: An introduction. Earthscan LTD, Dunstan House, London, UK.

FAO. (2010). Climate Smart Agriculture Policies, Practices and Financing for Food Security, Adaptation and Mitigation. FAO, Rome.

FAO. (2011). Women in Agriculture: Closing the gender gap for development. The State of Food and Agriculture 2010/2011. Rome: FAO.

FAO \& World Bank. (2011). Identifying Opportunities for Climate Smart Agriculture Investments in Africa. FAO $\&$ World Bank Final report.

FAO. (2013). Climate Smart Agriculture Sourcebook on Climate Smart Agriculture, Forestry and Fisheries. FAO, Rome.

Guei, R. G., Barra, A. \& Silue, D. (2011). Promoting smallholder seed enterprises: quality seed production of rice, maize, sorghum and millet in northern Cameroon. International Journal of Agricultural Sustainability, 91(1), 91-99. https://doi.org/10.3763/ijas.2010.0573

Katungi, E., Edmeades, S., \& Smale, M. (2008). Gender, social capital and information exchange in rural Uganda. Journal of International Development, 20(1), 35-52. https://doi.org/10.1002/jid.1426

Kondylis, F., Mueller, V., Sheriff, G., \& Zhu, S. (2016). Do Female Instructors Reduce Gender Bias in Diffusion of Sustainable Land Management Techniques? Experimental Evidence From Mozambique. World Development, 78, 436-449. https://doi.org/10.1016/j.worlddev.2015.10.036

Lipper, L., Thornton, P., Campbell, B. M., Baedeker, T., Braimoh, A., \& Torquebiau, E. F. (2014). Climate Smart Agriculture for Food Security. Nature Climate Change, 4(2014), 1068-1072.

https://doi.org/10.1038/nclimate2437 
Okry, F., Van Mele, P., Nuijten, E., Struik, P. C., \& Mongbo, R. L. (2011). Organizational analysis of the seed sector of rice in Guinea: Stakeholders, perception and institutional linkages. Experimental Agriculture, 47(1), 137-157. https://doi.org/10.1017/S001447971000089X

Resurrección, B. P., Bee, B. A., Dankelman, I., Park, C. M. Y., Halder, M., \& McMullen, C. P. (2019). Gender-transformative climate change adaptation: advancing social equity. Background paper to the 2019 report of the Global Commission on Adaptation. Rotterdam and Washington, DC.

Seboka, B., \& Deressa, A. (2000). Validating the farmers' indigenous social networks for local seed supply in central Rift valley of Ethiopia. Journal of Agricultural Education and Extension, 6, 245-254. https://doi.org/10.1080/13892240085300071

Sogani, R. (2011). Documentation of climate change perceptions and adaptation practices in Uttarakhand, Northern India. Beej Bachao Andolan-Save Seed Campaign, PANAP, Malaysia.

Tripp, R., \& Rohrbach, D. D. (2001). Policies for African Seed Enterprise. Food Policy, 26, 147-161. https://doi.org/10.1016/S0306-9192(00)00042-7

Van Aelst, K., \& Holvoet, N. (2016). Intersections of Gender and Marital Status in Accessing Climate Change Adaptation: Evidence from Rural Tanzania. World Development, 79, 50-60. https://doi.org/10.1016/j.worlddev.2015.11.003

Van Mele, P., Bentley, J., \& Guei, R. (2011). African Seed Enterprises, Sowing the Seed of Food Security. FAO and Africa Rice Center. https://doi.org/10.1079/9781845938437.0000

Whitehouse, B. (2011). Enterprising strangers: social capital and social liability among African migrant traders. International Journal of Social Inquiry, 4(1), 93-111.

Wiggins, S., \& Cromwell, E. (1995). NGOs and seed provision to smallholders in developing countries. World Development, 23, 413-422. https://doi.org/10.1016/0305-750X(94)00133-J

World Bank. (2008). Gender in Agriculture Sourcebook. Washington, DC: The World Bank; Rome: Food and Agriculture Organization of the United Nations and International Fund for Agricultural Development. Retrieved from http://hdl.handle.net/10986/6603

World Bank \& CIAT. (2015). Climate Smart Agriculture in Kenya. CSA Country Profiles for Africa, Asia, and Latin America and the Caribbean Series. Washington D.C.: The World Bank Group.

Zossou, E., Arouna, A., Diagne, A., \& Agboh-Noameshie, A. R. (2020). Learning agriculture in rural areas: the drivers of knowledge acquisition and farming practices by rice farmers in West Africa. The Journal of Agricultural Education and Extension, 26(3), 291-306. https://doi.org/10.1080/1389224X.2019.1702066

Zossou, E., Arouna, A., Diagne, A., \& Agboh-Noameshie, A. R. (2017). Gender Gap in Acquisition and Practice of Agricultural Knowledge: Case Study of Rice Farming in West Africa. Experimental Agriculture, 53(4), 566-577. https://doi.org/10.1017/S0014479716000582

Zoundji, C. G., Witteveen, L., Vodouhê, S. D., \& Lie, R. (2017). When baobab flowers and rainmakers define the season: farmers' perceptions and adaptation strategies to climate change in West Africa. International Journal of Plant, Animal and Environmental Sciences, 7(2). https://doi.org/10.21276/Ijpaes

Zoundji, V. S., Okry, F., Bentley, J. W., \& Tossou, R. C. (2018). Beyond Striga Management: Learning Videos Enhanced Farmers' Knowledge on Climate Smart Agriculture in Mali. Sustainable Agriculture Research, 7(1), 80-9. https://doi.org/10.5539/sar.v7n1p80

\section{Copyrights}

Copyright for this article is retained by the author(s), with first publication rights granted to the journal.

This is an open-access article distributed under the terms and conditions of the Creative Commons Attribution license (http://creativecommons.org/licenses/by/3.0/). 